\title{
Paradigm versus paradox on the prairie: testing competing stream fish movement frameworks using an imperiled Great Plains minnow
}

\author{
Zachary D. Steffensmeier ${ }^{1,2^{*}} \mathbb{D}$, Maeghen Wedgeworth ${ }^{3}$, Lauren Yancy ${ }^{1}$, Noah Santee ${ }^{1}$, Shannon K. Brewer ${ }^{4}$ and
} Joshuah S. Perkin ${ }^{1,2}$

\begin{abstract}
Background: Movement information can improve conservation of imperiled species, yet movement is not quantified for many organisms in need of conservation. Prairie chub (Macrhybopsis australis) is a regionally endemic freshwater fish with unquantified movement ecology and currently considered for listing under the Endangered Species Act. The purpose of this study was to test competing ecological theories for prairie chub movement, including the colonization cycle hypothesis (CCH) that posits adults must make upstream movements to compensate for downstream drift at early life stages, and the restricted movement paradigm (RMP) that describes populations as heterogeneous mixes of mostly stationary and few mobile fish.
\end{abstract}

Methods: We tagged prairie chub with visible implant elastomer during the summer (May-August) of 2019 and 2020 to estimate net distance moved $(\mathrm{m})$ and movement rate $(\mathrm{m} / \mathrm{d})$. We tested the hypotheses that observed prairie chub movement would be greater than expected under the RMP and that prairie chub movement would be biased in an upstream direction as predicted by the $\mathrm{CCH}$.

Results: We tagged 5771 prairie chub and recaptured 213 individuals across 2019 and 2020. The stationary and mobile components of the prairie chub population moved an order of magnitude further and faster than expected under the RMP during both years. However, we found only limited evidence of upstream bias in adult prairie chub movement as would be expected under the $\mathrm{CCH}$.

Conclusions: Our findings are partly inconsistent with the RMP and the $\mathrm{CCH}$, and instead closely follow the drift paradox (DP), in which upstream populations persist despite presumed downstream drift during early life stages and in the apparent absence of upstream bias in recolonization. Previous mathematical solutions to the DP suggest organisms that experience drift maintain upstream populations through either minimization of drift periods such that small amounts of upstream movement are needed to counter the effects of advection or increasing dispersal regardless of directionality. We conclude that the resolution to the DP for prairie chub is an increase in total dispersal and our results provide insight into the spatial scales at which prairie chub conservation and management may need to operate to maintain broad-scale habitat connectivity.

*Correspondence: steffensmeierz@tamu.edu

${ }^{1}$ Department of Ecology and Conservation Biology, Texas A\&M University, College Station, TX, USA

Full list of author information is available at the end of the article permits use, sharing, adaptation, distribution and reproduction in any medium or format, as long as you give appropriate credit to the original author(s) and the source, provide a link to the Creative Commons licence, and indicate if changes were made. The images or other third party material in this article are included in the article's Creative Commons licence, unless indicated otherwise in a credit line to the material. If material is not included in the article's Creative Commons licence and your intended use is not permitted by statutory regulation or exceeds the permitted use, you will need to obtain permission directly from the copyright holder. To view a copy of this licence, visit http://creativecommons.org/licenses/by/4.0/. The Creative Commons Public Domain Dedication waiver (http://creativeco mmons.org/publicdomain/zero/1.0/) applies to the data made available in this article, unless otherwise stated in a credit line to the data. 
Keywords: Drift paradox, Pelagic-broadcast spawning, Restricted movement paradigm, Colonization cycle hypothesis, Dispersal, Conservation biology

\section{Background}

Understanding movement ecology of aquatic organisms has the potential to advance conservation and management of water resources [1]. Despite this potential, knowledge of movement by organisms was historically underrepresented in environmental management decisions for nongame species until recently when applied movement ecology emerged as a research framework [2-4]. For example, Fraser et al. [5] found that movement ecology information was incorporated into conservation planning most of the time when such data were available, but movement information was unknown for some at risk species. Allen and Singh [6] developed a five-step framework for integrating movement ecology into conservation planning, beginning with the measurement of movement attributes and extending to assessing organism effects on ecosystems, how this information can be incorporated into management, implementation of management actions, and finally evaluation of actions. Although this framework will provide beneficial information for animal conservation across taxa and ecosystems, it is particularly needed for imperiled stream fishes [2]. Specifically, there is a need to better understand the scales at which non-game or otherwise non-economically important stream fishes complete their life histories so that this information can be integrated into management and conservation actions [7].

Fish movement in streams received considerable attention during the past 70 years. Early works on stream fish dispersal documented largely restricted movements characterized by most individuals remaining near the site of tagging when recaptured [8,9]. During this same early period, Funk [10] reported that fish populations in streams in Missouri, United States were composed of mixtures of sedentary fish that did not move far from the tagging location and mobile fish that moved greater distances. Despite observations by Funk [10], Gerking's [9] conclusion of restricted movement by stream fishes was the prevailing regime for more than 30 years. Gowan et al. [11] reviewed fish movement literature and coined the term restricted movement paradigm (RMP) to emphasize the prevailing pattern of little movement by stream fishes. However, in the same work that derived the RMP, Gowan et al. [11] emphasized that stream fish movement studies focused too narrowly on habitats in which fish were marked and that fish populations were generally more mobile than reported. Rodriguez [12] later suggested that studies critical of the RMP were focused too heavily on a subset of Salmonidae fishes with high mobility; thus, the RMP was incomplete because it only acknowledged stationary fishes while ignoring mobile components of populations. Collectively, these works pointed to stream fish movement being heterogeneous and consisting of both "stationary" or "slow-moving" individuals and "mobile" or "fast-moving" individuals [13]. The signals of heterogeneous populations composed of stationary and mobile individuals (i.e., leptokurtic movement distributions) formed the basis of contemporary stream fish dispersal models [14]. In particular, Radinger and Wolter [14] used two overlapping normal distributions, one with a taller peak at zero movement (stationary fish) and a second with a shorter peak but broader base (mobile fish) to conduct a meta-analysis of movement by 40 species of stream fishes. Radinger and Wolter [14] developed predictions for stream fish movement under this new implementation of the RMP based on fish size, stream size, fish caudal fin aspect ratio $\left(\mathrm{A}=\right.$ height ${ }^{2} /$ surface area), and the length of time fish are at large (i.e., time between tag and recapture). These predictions are validated for several species including banded sculpin [15] and plains killifish [16]. However, tests of the RMP on a broader range of fishes are ultimately needed to determine if this theoretical framework is broadly applicable or subject to context dependencies.

A concept contrary to the RMP is the "colonization cycle hypothesis" $(\mathrm{CCH})$, which posits that stream organisms that experience some degree of drift must move upstream to compensate for downstream displacement $[17,18]$. The $\mathrm{CCH}$ predicts that most of the adult population must move a net distance upstream based on the downstream displacement of ova and larvae during drift. However, the $\mathrm{CCH}$ does not explain the upstream persistence of non-aerial adult macroinvertebrates that apparently do not make mass upstream movements to compensate for downstream drift [19]. Consequently, the "drift paradox" (DP) was developed to articulate the apparent contradictory pattern in which drifting stream organisms that are displaced, sometimes great distances downstream during early life stages, can maintain upstream populations [20]. Since its inception, much of the work on the DP has focused on aquatic invertebrates $[19,21]$ or model simulations $[22,23]$. Proposed resolutions to the DP include the process of density dependence, random directional dispersal at the adult stage, and at least partial retention of larvae at upstream sites [24]. Recently, application 
of the DP has spanned beyond aquatic invertebrates as linkages between the DP and dispersal of a guild of stream fishes known as "pelagic-broadcast spawning" (PBS) fishes were established [25, 26].

Fishes belonging to the PBS reproductive guild spawn nearly neutrally buoyant eggs within the water column, which then develop as they are swept downstream [2729]. Model simulations predict that eggs and developing ova can be transported long distances downstream, ranging 131-147 km and 468-592 km [30, 31], depending on stream size and habitat heterogeneity [32]. The concept of retention of eggs and ova at upstream locations for some PBS fishes has spurred much debate [33-39] and there is a general paucity of information on the movements of adult PBS fishes based on their diminutive size, and challenges associated with tagging and tracking individuals over broad spatial extents and in large rivers [15, 40]. Existing studies suggest upstream movement by PBS fishes occurs [25, 41] and is altered by stream fragmentation $[42,43]$. However, evidence of biased upstream movement by PBS fishes, as predicted by the $\mathrm{CCH}$, is lacking and additional research on the movement of PBS fishes is necessary, particularly the adult life stage when biased upstream movement is hypothesized to occur (e.g., [30]). Pelagicbroadcast spawning fishes have a unique reproductive mode (particularly in freshwater; [44]), and future research should focus on how this life history strategy relates to movement ecology and conservation biology [40].

Conservation of PBS fishes requires that movement information be integrated into conservation and spatial planning, but a necessary first step is that movement attributes be measured and framed in the context of prevailing theories [6]. Declines in populations of PBS fishes have been shown in fragmented streams, suggesting that a critical fragment length that does not restrict movement may play a role in recruitment success $[36,40$, 45]. Cyprinids in the genus Macrhybopsis would benefit from conservation to prevent widespread extirpations, but the mechanisms by which known causes of decline operate are unknown despite indirect references to the $\mathrm{CCH}[40,46,47]$. As with other PBS fishes, Macrhybopsis spp. eggs are transparent, non-adhesive, and become semi-buoyant in water, therefore ova are hypothesized to be subjected to long-distance downstream dispersal [27, 28, 31]. Macrhybopsis therefore represent an ideal group for testing the applicability of the RMP versus the $\mathrm{CCH}$. In particular, prairie chub (Macrhybopsis australis) was designated as a PBS species in recent research [48], has egg characteristics consistent with other PBS fishes [40], and is commonly included within the assemblage of PBS fishes in the Great Plains $[48,49]$.
Prairie chub is a short-lived fish endemic to the Red River basin of Texas and Oklahoma, USA with a reproductive season spanning April through September [48]. Other life history characteristics include a diet that consists primarily of aquatic macroinvertebrates, a lifespan of 2 years [48] and a maximum size of $70 \mathrm{~mm}$ total length (TL, [50]). Prairie chub is a species in need of conservation in both Texas and Oklahoma, was listed as "Vulnerable" by Jelks et al. [51], "Threatened" in Texas, and is currently under consideration for listing under the U.S. Endangered Species Act [52]. The species is susceptible to local extirpations, especially in fragmented reaches isolated by dams (e.g. extirpation of prairie chub above Lake Altus; [53]) and subject to stream dewatering in the Red River basin [40, 45, 50]. Furthermore, potential for increased drought frequency and anthropogenic water withdrawals may have a synergistic and negative effect on prairie chub by drying habitats [54, 55]. However, drought is a natural phenomenon in the southern Great Plains that has shaped adaptations by fishes [56], including source-sink population dynamics connected by movement along river corridors [57]. Consequently, movement is likely a critical aspect of prairie chub persistence, but little is known about movement patterns for the species outside of inference gained from spatial patterns in occurrence [48].

The purpose of this study was to test the applicability of the RMP versus the $\mathrm{CCH}$ and DP in describing the movement ecology of prairie chub. We hypothesized that prairie chub movement would be greater than expected under the RMP (H1) because of anecdotal evidence of long-range movements by prairie chub [48] and empirical evidence of such movements by other Great Plains PBS fishes [26, 41]. We also hypothesized that movement would be upstream biased $(\mathrm{H} 2)$ consistent with $\mathrm{CCH}$ as adult fish move upstream to compensate for downstream drift of eggs and larvae [27, 28, 31]. We concluded that support for the RMP would exist if $\mathrm{H} 1$ and $\mathrm{H} 2$ were rejected (Fig. 1a), while support for the $\mathrm{CCH}$ would exist if both $\mathrm{H} 1$ and $\mathrm{H} 2$ were supported (Fig. 1d). Support for one hypothesis but not the other is consistent with a paradoxical pattern in which upstream movement to compensate for downstream drift is not evident, and thus evokes the DP (Fig. 1b, c). We then used the results of these hypothesis tests to inform conservation by projecting prairie chub movement across the study area to illustrate the scale of movement by the species in a spatially-explicit manner.

\section{Methods}

\section{Study area}

We studied the movement ecology of prairie chub in the upper Red River basin located in the Central Lowlands 


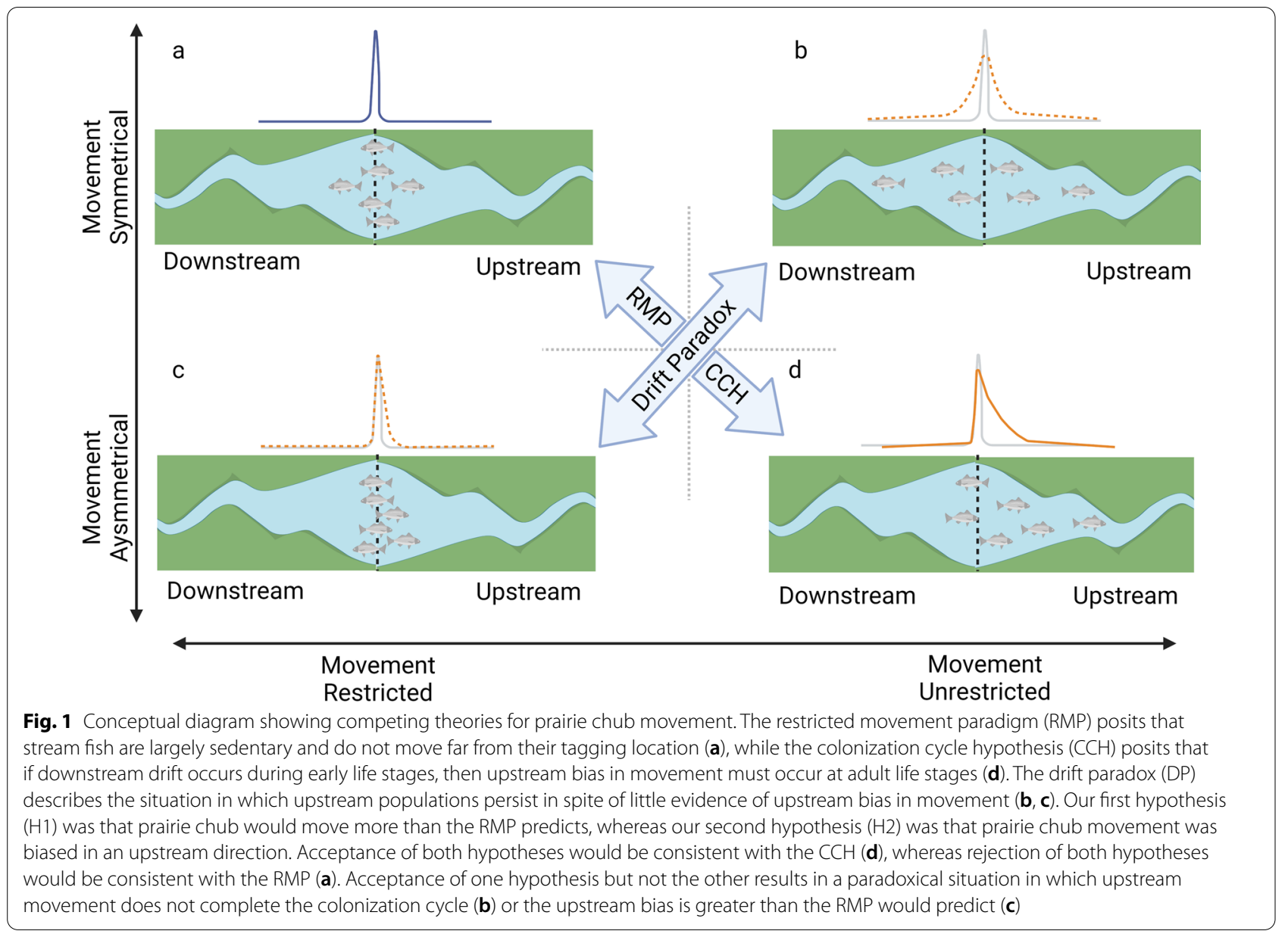

physiographic province of Oklahoma and Texas, USA. This semi-arid region receives, on average, $82 \mathrm{~cm}$ of precipitation annually, and has a mean annual air and water temperature of $18.0^{\circ} \mathrm{C}$ and $19.3{ }^{\circ} \mathrm{C}$, respectively [58]. The Red River is characterized by a gently sloping floodplain with a sandy bed that may be up to a kilometer wide and experiences unpredictable seasonal flow variability [58]. Land use in this area is primarily agricultural, with $80-90 \%$ being used for rangeland and cropland that is both irrigated and unirrigated [58]. We focused on six sites: two on the Red River (6th order, [59]), two on the Salt Fork Red River (5th order), and two on the Pease River (5th order; Fig. 2). We selected these streams because they are inhabited by prairie chub but occur upstream of a zone of hybridization with closely related shoal chub (M. hyostoma; [60]). Daily discharge was monitored throughout our study period by the United States Geological Survey ([61]; Additional File 1) on the Pease River at Vernon, Texas (USGS gage 07308200), the Salt Fork Red River at Elmer, Oklahoma (USGS gage 07301110), and the Red River proper at Burkburnett, Texas (USGS gage 07308500).

\section{Survival and tag retention}

We first assessed tag retention and survival to determine the minimum total length $(\mathrm{mm})$ of prairie chub that could be tagged in the movement experiment. We conducted two 24-h tagging trials using a 68 -L perforated tub placed in the Red River at the state highway 283 access point. Fish were individually netted and tagged by injecting visible implant elastomer (VIE) into the muscle tissue just under the scales with a single 2-mm fluorescent elastomer mark (Northwest Marine Technology Inc.) using a $0.3-\mathrm{mL}$ syringe and a 27 -gauge, $12-\mathrm{mm}$ long needle. Colored elastomer was injected as the needle was withdrawn, creating a streak until the bevel of the needle reached the injection point [62]. The first trial took place on July 23, 2019 and included one treatment group (single VIE tag, $\mathrm{n}=24$ ) and one control group (untagged, $\mathrm{n}=24$ ). The second trial took place on August 5, 2019 and included two treatment groups (single tag, $\mathrm{n}=23$; double tag, $\mathrm{n}=24$ ) and one control group (untagged, $n=23$ ). For each of these trials, we collected prairie chub from the mainstem Red River and pooled all collected fish in a single tub. We 


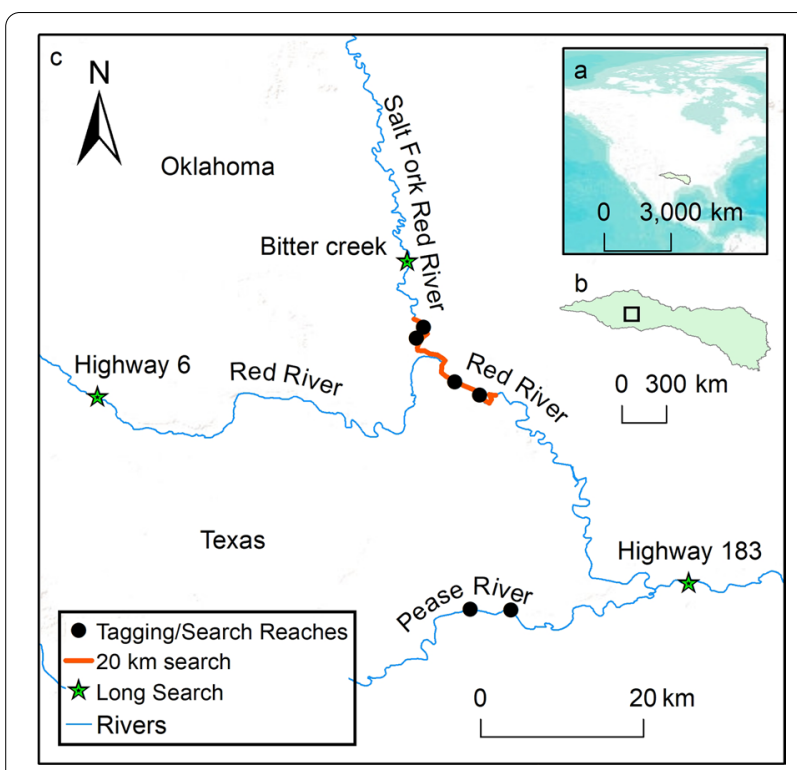

Fig. 2 Sample sites located within North America (panel a) in the Red River basin (panel b) that were used in our mark-recapture analyses of prairie chub movement. Tagging and searching sites were located on the Salt Fork Red River, the Red River, and the Pease River (panel c). The long searches were completed August 8-9, 2020 to look for relatively long-distance movers outside of our tagging and regular search sites. The 20-km search was completed August 10-12, 2020 to systematically look for tagged prairie chub above and below 4 of 6 sites along the Salt Fork Red River and the Red River (August 10-12, 2020). NHDplus flowline was used for the rivers [58]

then randomly netted fish one at a time from the tub and alternated assignment to control and treatment groups that were housed in separate tubs [63]. Control group fish were handled but not tagged or measured, single tag fish received one dorsal VIE tag at the posterior end of the caudal peduncle and were measured for total length, and double tag fish received two dorsal VIE tags at the posterior end of the caudal peduncle and were measured for total length. At the completion of the 24-h trials, fish were classified as retaining (tag still present on fish body) or shedding (tag not evident) their tag and as alive or dead [64]. Attempts to measure tag retention over longer time periods were unsuccessful due to logistical challenges caused by holding fish in captivity.

We analyzed survival using generalized linear regression in the form of a multiple logistic regression model [64], where survival was a binomial response $(0=$ dead, $1=$ alive), length was a continuous independent variable, and treatment was a categorical factor (control, single tag, double tag). We did not model tag retention because all fish retained their tags during the trials. We used the 'glm' function from the 'stats' package in $\mathrm{R}$ (version 4.0.4) to fit the model and used the length at which survival equaled 0.50 probability as the minimum size fish to tag in the movement experiment.

\section{Movement experiment}

We assessed movement of prairie chub using a markrecapture experiment with multiple tag and recapture events during late spring through summer (i.e., MayAugust) of 2019 and 2020. At each of the six locations, we established a 1-km tagging reach buffered upstream and downstream by $1-\mathrm{km}$ search reaches. In the Red River and Salt Fork Red River, the two tagging reaches were distributed so that they were $1-\mathrm{km}$ apart, resulting in a shared search reach in the middle (Additional File 2). Each 1-km tagging reach was divided into five 0.2$\mathrm{km}$ sub-reaches where fish were batch tagged using VIE. We collected fish for tagging from each sub-reach using four $50-\mathrm{m}$ seine hauls $(9.1-\mathrm{m}$ by $1.8-\mathrm{m}, 1-\mathrm{m}$ shallowbag, tapering to $0.5-\mathrm{m}$ ) repeated three times (i.e., triplepass). We ultimately elected to mark fish with VIE for the movement study because this method is widely used in fish movement studies, has minimal mortality (including in our own study; see "Results" section), and small fishes tagged with VIE demonstrated no behavioral changes caused by tagging in previous fish movement studies [65-67].

Fish captured during each pass were held together in a $68 \mathrm{~L}$ perforated tub (to allow oxygenated stream water to flow through) for batch tagging with VIE. We used a subset of 140 potential unique combinations of VIE colors and body locations to ensure fish could be traced back to the sub-reach and date in which they were tagged (Additional File 2). We recorded the date, VIE color, body location of the tag, and total length (to nearest 1-mm) for each tagged fish and placed them in a second aerated 68-L recovery tub for $2 \mathrm{~h}$ prior to release [15]. We recorded global positioning system (GPS) coordinates at the release site (i.e., center of sub-reach) for all fish using a handheld Oregon 700 series GPS (Garmin, Olathe, KA, USA). Fish that were recaptured more than once were treated as independent data points and movement was measured from the last release location.

For both study years, we conducted tagging and recapturing events at 2-6-week intervals in each of the three streams (Table 1). During each visit, we spent two consecutive days tagging fish and then conducted recapture searches across all search and tagging reaches on the third day. This approach resulted in an increasing number of fish tagged throughout the summer and provided opportunity to recapture fish over a wider range of time periods. We made recaptures by conducting $50-\mathrm{m}$ seine hauls across the entire search and tagging reaches (Additional File 2). On August 8-9, 2020, we searched three far distance sites using 50-m seine hauls across a $2-\mathrm{km}$ extent 
Table 1 Sampling dates of prairie chub (Macrhybopsis australis) during summers of 2019 and 2020 for the Red River, Salt Fork Red River, and Pease River in the Red River Basin of Texas and Oklahoma, USA showing the number of fish tagged (T) and recaptured (R) and discharge (cubic meters per second)

\begin{tabular}{|c|c|c|c|c|c|c|c|}
\hline Summer 2019 & River & $T(R)$ & Flow (cms) & Summer 2020 & River & $T(R)$ & Flow (cms) \\
\hline Jun. 5-11 & Pease & $86(4)$ & 15.12 & Jun. 19-22 & Pease & $332(2)$ & 0.44 \\
\hline Jul. 16-17 & Pease & $88(0)$ & 1.08 & Jul. 7-9 & Pease & $27(1)$ & 1.16 \\
\hline Jul. 31-Aug. 2 & Pease & $110(1)$ & 0.24 & Jul. 24-26 & Pease & $11(1)$ & 0.37 \\
\hline Aug. 9-12 & Pease & $95(2)$ & 0.02 & - & - & - & - \\
\hline Total & Pease & $379(7)$ & & Total & Pease & $370(4)$ & \\
\hline May $15-18$ & Red & $576(3)$ & 302.99 & Jun. 16-18 & Red & $955(13)$ & 5.52 \\
\hline Jun. 25-27 & Red & $113(6)$ & 61.45 & Jul. 4-6 & Red & $404(19)$ & 5.10 \\
\hline Jul. 19-22 & Red & $95(2)$ & 27.92 & Jul. 21-23 & Red & $677(12)$ & 2.97 \\
\hline Aug. 3-5 & Red & $96(1)$ & 14.53 & Aug. 12 & Red & NA(18) & 2.18 \\
\hline Total & Red & $880(12)$ & & Total & Red & $2036(62)$ & \\
\hline Jun. 28-Jul. 1 & Salt Fork & $59(1)$ & 4.87 & Jun. 24-26 & Salt Fork & $284(4)$ & 1.10 \\
\hline Jul. 23-25 & Salt Fork & 191(3) & 3.23 & Jul. 17-19 & Salt Fork & $404(26)$ & 0.76 \\
\hline Aug. 6-8 & Salt Fork & $436(20)$ & 2.75 & Aug. 4-6 & Salt Fork & $178(18)$ & 0.31 \\
\hline Aug. 13-15 & Salt Fork & $541(51)$ & 3.14 & Aug. 10-11 & Salt Fork & NA(5) & 0.27 \\
\hline Total & Salt Fork & $1227(75)$ & & Total & Salt Fork & $866(53)$ & \\
\hline Grand Total & All & 2486(94) & & Grand Total & All & $3272(119)$ & \\
\hline
\end{tabular}

The final sampling dates for the Red River and Salt Fork Red River in August 2020 were long distance searches and no fish were tagged

of stream upstream and downstream of the mainstem Red River site (Fig. 2). On August 10-12, 2020, we completed a $20-\mathrm{km}$ (i.e., $40050-\mathrm{m}$ consecutive seine hauls) long-distance search for recaptures from the Salt Fork Red River to the Red River mainstem across 4 of our 6 study sites (i.e., excluding the Pease River tributary sites; Fig. 2). All fish captured during long distance searches were visually scanned for VIE tags independently by two observers. Recapture efforts targeted habitats most likely to be inhabited by chub [68], including habitats near the stream thalweg where water is deepest and fastest. We recorded date, total length $(\mathrm{mm})$, GPS coordinates, VIE color, and body tagging location for each recapture.

\section{Restricted movement paradigm}

We tested the hypothesis that prairie chub would move further distances than expected under the RMP (H1) using the R package 'fishmove' [14]. We first estimated expected movements using the function 'fishmove', which generates a double-normal distribution of movement distances at the population level using stream size (stream order; [59]), fish length (total length, $\mathrm{mm}$ ), fish morphology (aspect ratio of caudal fin; [69]), and time at large (days, $d$ ) based on the meta-analysis conducted by Radinger and Wolter [14]. We parameterized the expected movement model with the largest stream order we studied (6th order), the median length $(\mathrm{mm}$ TL) of adult individuals we captured during this study (54-mm in $2019 ; 58-\mathrm{mm}$ in 2020 ), a caudal fin aspect ratio we estimated from scientific images of prairie chub (1.09; [70]), and the median number of days between mark and recapture for all recaptured fish in our study ( 8 d in 2019; $18 \mathrm{~d}$ in 2020). This function provides an estimate and $95 \%$ confidence interval for distances moved by the stationary (sigma-stat) and mobile (sigma-mob) components of the population. Next, we estimated a movement distribution curve from our mark-recapture field data using the function 'fishmove. estimate', which fits a double normal distribution to a vector of movement distances observed in the field to generate estimates of distances moved by mobile and stationary components of the population. We then assessed whether the estimate for observed movement fell within the $95 \%$ confidence intervals of the expected movement and accepted $\mathrm{H} 1$ if the observed movement distance was greater than the upper 95\% confidence interval for expected movement. We repeated this test for 2019 and 2020 separately, for net movement, defined as the linear distance $(\mathrm{m})$ between tagging and recapture locations along the stream thalweg, which was measured using the network analyst function in ESRI ArcGIS (ESRI, Redlands, CA). We also used daily movement rate $(\mathrm{m} / \mathrm{d})$, defined as net distance moved divided by the number of days between tagging and recapture. We estimated the expected movement rate by changing the time interval in the function 'fishmove' from $8 \mathrm{~d}$ (2019) or $18 \mathrm{~d}$ (2020) to $1 \mathrm{~d}$ so that estimates of movement distance were standardized by time. 


\section{Colonization cycle hypothesis}

We tested the hypothesis that prairie chub exhibited biased upstream movement expected with the $\mathrm{CCH}(\mathrm{H} 2)$ using frequency histograms and distances/rates moved upstream versus downstream. We tested for skewness, kurtosis, and upstream bias based on 2019 and 2020 recapture data. We tested normality and kurtosis of net movement $(\mathrm{m})$ and daily movement rate $(\mathrm{m} / \mathrm{d})$ distributions using D'Agostino's test for normality [71] and Anscombe Glynn's test of kurtosis [72] following previous methodologies $[15,73,74]$. We tested our hypothesis that prairie chub net movement $(\mathrm{m})$ and daily movement rate $(\mathrm{m} / \mathrm{d})$ was biased in an upstream direction (H2) using a Mann-Whitney $U$ test implemented with the 'wilcox.test' function in R [75]. We converted the distances moved upstream versus downstream to absolute values (i.e., instead of representing downstream distances with a negative value) and then tested for differences between the ranks of distances in either direction. All functions were executed in $\mathrm{R}$ version 4.0.4 ( $\mathrm{R}$ Core Team 2021; Additional File 3).

\section{Conservation implications}

We investigated the conservation implications of the results from our hypothesis testing with respect to the scale of prairie chub movement. The mobile component of populations is critical for connecting meta-populations and recolonization of habitat $[12,76]$, including prairie chub in particular [48]. Consequently, we compared the movement rate $(\mathrm{m} / \mathrm{d})$ for the mobile component of the prairie chub population with all other species included in the work by Radinger and Wolter [14]. The list of species made up of several different fish families is included in the $\mathrm{R}$ package 'fishmove' and is available within the package ('fishmove:::speciesfishmove'). We estimated the daily (i.e., time $=1 \mathrm{~d}$ ) movement of the mobile component for each of these species. We then plotted the daily movement rate for the mobile component of the prairie chub population from our study for 2019 and 2020 separately to illustrate the contrast between prairie chub movement and movement by other river fishes analyzed by Radinger and Wolter [14]. Next, we estimated the range (i.e., maximum distance that prairie chub might move) for the mobile component by multiplying the estimated movement rate $(\mathrm{m} / \mathrm{d})$ by 123 days, which encompassed the summer season for which we collected movement data (May 1 through August 31). Greater movement might be possible if time periods outside of this season are included, but we did not measure movement for other seasons. We calculated potential ranges for 2019 and 2020 separately and then used the locations of our tagging as source locations to estimate the upstream and downstream ranges of prairie chub. The resulting spatial extent of the prairie chub range may effectively provide a footprint of scale for future conservation and management decisions.

\section{Results}

\section{Survival and tag retention}

Prairie chub tag retention and survival were generally high. Both trials had a tag retention rate of $100 \%$ after $24 \mathrm{~h}$. The control group experienced $100 \%$ survival. Survival of the single tag treatment group was 98\% [46 of 47], and survival of the double tag treatment group was $75 \%$ [18 of 24]. Results from the regression model showed a significant treatment effect $(\mathrm{Z}=2.36, p=0.02)$ and a significant effect of length $(Z=2.66, p=0.01)$. The only mortality in the single tag treatment group was a fish that was $35-\mathrm{mm}$ TL, the smallest fish in the treatment group. The six mortalities in the double tag treatment group included the five smallest fish (range $=38-40 \mathrm{~mm} \mathrm{TL}$ ) and one fish that was $58-\mathrm{mm} \mathrm{TL}$. The probability of survival exceeded 0.50 for double-tagged fish at $45-\mathrm{mm}$ TL (Fig. 3), and we did not double-tag fish in the movement experiment if they were less than this length.

\section{Movement experiment}

Prairie Chub movement was determined by using markrecapture methods during four visits to each site during

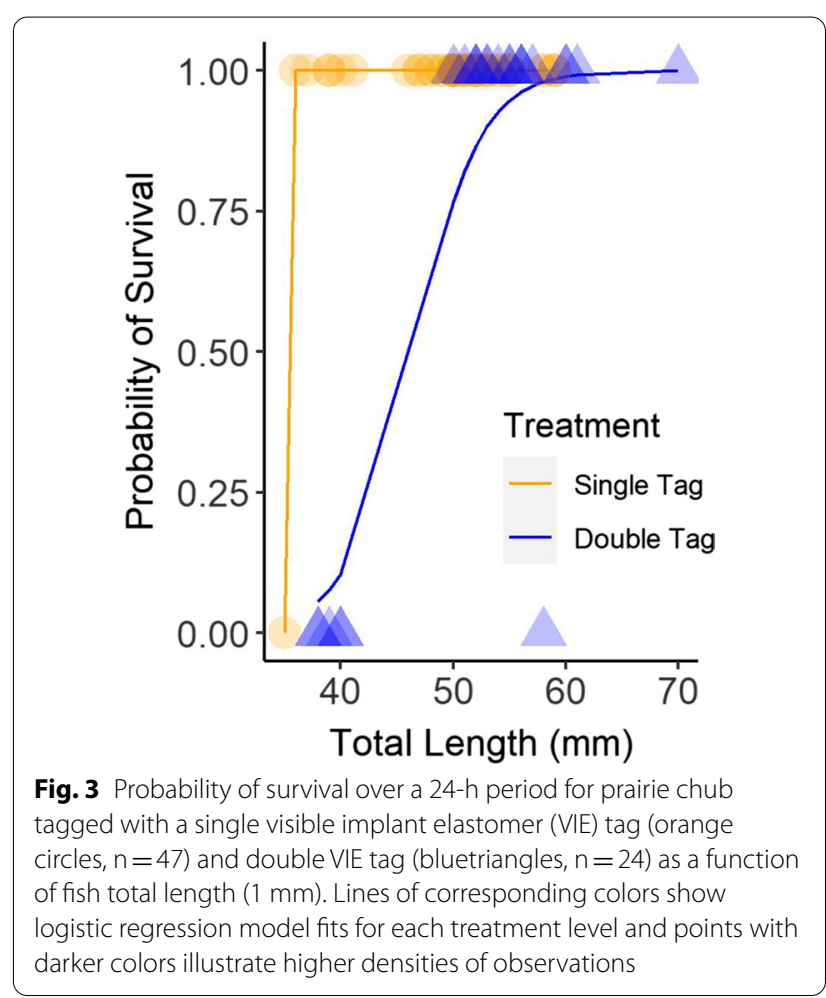


2019 and three visits to each site during 2020. We tagged 5771 prairie chub during summer $2019(\mathrm{n}=2499)$ and $2020(\mathrm{n}=3272)$ and recaptured 213 fish across both summer $2019(n=94)$ and summer $2020(n=119)$. The average length of fish recaptured was 54-mm TL (range 42-70) during 2019 and 58-mm TL (range 48-67) during 2020. Fish were at large for an average of $11 \mathrm{~d}$ in 2019 (median $=8$, range $=1-57$ ) and $17 \mathrm{~d}$ in 2020 (median $=18$, range $=1-68$ ). A single fish that was tagged in summer 2019 was recaptured during summer 2020. This fish was tagged at the lower site in the Red River on July 21, 2019 and was recaptured at the lower site on the Salt Fork River on July 17, 2020. The prairie chub moved at least $11,745 \mathrm{~m}$ upstream over $362 \mathrm{~d}$ (movement rate $=32.4 \mathrm{~m} / \mathrm{d}$ ). We removed this observation from our analysis because it represented the only recapture between the two summers. We recaptured two and three individuals that were double recaptured in 2019 and 2020, respectively, which were treated as new recaptures for the purpose of analysis. All movement distributions were leptokurtic, including net distance moved in 2019 (Additional File 4a, kurtosis $=15.3$, $\mathrm{z}=5.70, p$ value $<0.01$ ) and 2020 (Additional File $4 \mathrm{~b}$, kurtosis $=5.57, \mathrm{z}=3.39, p$ value $<0.01)$ and daily movement rate for 2019 (Additional File 4c, kurtosis $=12.7$, $\mathrm{z}=5.34, p$ value $<0.01$ ) and 2020 (Additional File 4d, kurtosis $=21.9, \mathrm{z}=6.76, p$ value $<0.01)$. We recaptured very few tagged fish outside of our usual survey extents. The long-distance searches at state highway 6 , state highway 183 , and below the confluence of Bitters Creek yielded no recaptured prairie chub. The $20-\mathrm{km}$ long distance search yielded recaptures that were all within the normal tagging and search reaches with the exception of one fish that moved $69 \mathrm{~m}$ below the Salt Fork lower search site.

\section{Restricted movement paradigm}

Observed prairie chub movement measured by distance and rate were consistently greater than expected under the RMP. The expected movement distances of the stationary and mobile components differed slightly between 2019 and 2020 (Table 2). Observed movement distances were consistently, and statistically, greater than expected across years and study systems (Fig. 4a-c). Similarly, the expected movement rates for 2019 were not significantly different between 2019 and 2020, but observed movement rates were consistently greater than expected across years and study systems (Fig. $4 \mathrm{~d}-\mathrm{f}$ ). The expected share of the stationary component $(p)$ for movement distance and rate was 0.67 , and the observed values for $p$ were close to this value during 2019 (distance $=0.79$; rate $=0.60)$ and 2020 (distance $=0.69$; rate $=0.63)$. Based on these data, we accepted $\mathrm{H} 1$ and concluded that prairie chub moved greater distances and at faster rates than expected under the RMP.

\section{Colonization cycle hypothesis}

There was limited evidence of upstream bias in adult (i.e., ages 1 and 2) prairie chub movement during the summers of 2019 and 2020. We found no difference in the distances or rates moved upstream versus downstream for 2019 or for 2020 based on Mann-Whitney $U$ tests of the pooled data, Red River only, or Salt

Table 2 Data from the expected ('fishmove') and observed ('fishmove.estimate') output from R for prairie chub movement distance and rate in the Red River, Salt Fork Red River, and Pease River in the Red River Basin of Texas and Oklahoma, USA during 2019 and 2020

\begin{tabular}{|c|c|c|c|c|c|c|}
\hline \multirow[t]{2}{*}{ River } & \multirow{2}{*}{$\begin{array}{l}\text { Movement } \\
\text { Metric }\end{array}$} & \multirow{2}{*}{$\begin{array}{l}\text { Movement } \\
\text { Component }\end{array}$} & \multicolumn{2}{|l|}{2019} & \multicolumn{2}{|l|}{2020} \\
\hline & & & Expected & Observed & Expected & Observed \\
\hline Pooled & Distance & Stationary & $2.1(0.7-5.8)$ & $158.6(131.7-185.6)$ & $3.3(1.26-8.7)$ & $242.8(197.8-287.8)$ \\
\hline Pooled & Distance & Mobile & $42.5(19.5-94.9)$ & 2169 (1647-2691) & $75.6(35.8-159.3)$ & $1391(1115-1668)$ \\
\hline Red & Distance & Stationary & $0.8(0.3-2.2)$ & $235.9(147.5-324.4)$ & $2.4(1.0-5.7)$ & $254(195.2-312.8)$ \\
\hline Red & Distance & Mobile & $12.6(5.6-28.1)$ & $1879.6(878.6-2881)$ & $50.2(25.7-98.4)$ & $1029(617.4-1441)$ \\
\hline Salt Fork & Distance & Stationary & $1.7(0.7-4.2)$ & $116(89.1-142.9)$ & $2.7(1.8-6.4)$ & $227(150.6-303.4)$ \\
\hline Salt Fork & Distance & Mobile & $32.3(16.0-65.4)$ & 1629 (1202-2056) & $57.7(30-111)$ & $1790(1234-2346)$ \\
\hline Pooled & Rate & Stationary & $0.9(0.3-2.7)$ & $8.6(6.9-10.2)$ & $1.0(0.3-3.0)$ & $21.2(14.5-27.9)$ \\
\hline Pooled & Rate & Mobile & $13.7(5.6-33.7)$ & 739.8 (619.8-859.8) & $15.0(6.2-36.5)$ & $258.2(212.9-303.6)$ \\
\hline Red & Rate & Stationary & $0.6(0.1-1.7)$ & $5.1(2.8-7.3)$ & $0.7(0.25-2.1)$ & $20.1(15.1-25.1)$ \\
\hline Red & Rate & Mobile & $8.5(3.6-19.9)$ & $947(597.2-1297)$ & $10.5(4.6-23.8)$ & $176.4(127.1-225.6)$ \\
\hline Salt Fork & Rate & Stationary & $0.7(0.2-2.0)$ & $9.5(7.6-11.5)$ & $0.8(0.3-2.2)$ & $46.4(39.7-53.1)$ \\
\hline Salt Fork & Rate & Mobile & $10.1(4.4-23.0)$ & 755.5 (602.7-908.2) & $11.2(5.0-25.2)$ & $410.1(364.8-455.5)$ \\
\hline
\end{tabular}

The pooled data (2019 $n=94$ recaptures, $2020 n=119)$ represents the Pease $(2019 n=7,2020 n=4)$, Red $(2019 n=12,2020 n=62)$, and Salt Fork $(2019 n=75,2020$ $\mathrm{n}=53$ ) rivers combined. We did not analyze the Pease River alone due to insufficient sample size. Distance (meters), Rate (meters per day). Values are fitted means (95\% confidence intervals) 

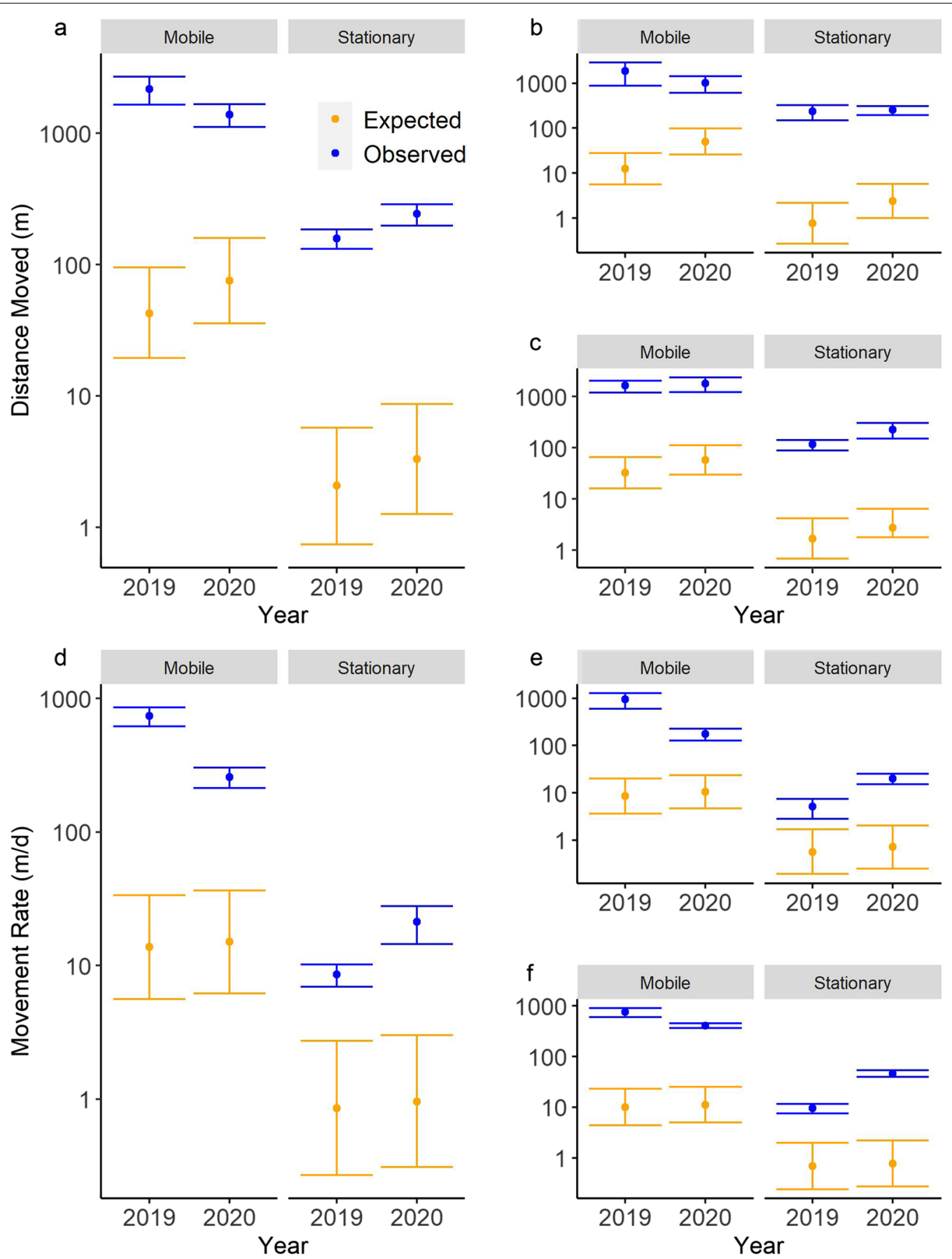

Fig. 4 Plot of expected (orange) versus observed (blue) prairie chub $(\mathbf{a}, \mathbf{b}, \mathbf{c})$ movement distances and (d, e, $\mathbf{f}$ ) movement rates for mobile (left) and stationary (right) components of the population measured during the summers of 2019 and 2020. The plot has pooled (a, d; $2019 \mathrm{n}=94,2020$ $n=119)$ data which contains all sites, the Red River (b, e; $2019 n=12,2020 n=62)$ only, and the Salt Fork River (c, $\mathbf{f} ; 2019 n=75,2020 n=53)$ only. The Pease River was not included due to low recapture numbers $(2019 n=7,2020 n=4)$. The orange bars around expected movements are upper and lower 95\% confidence intervals generated using the 'fishmove' function in R. The blue bars around observed movements are upper and lower 95\% confidence intervals calculated from the standard errors given from the 'fishmove.estimate' function in $\mathrm{R}$ 


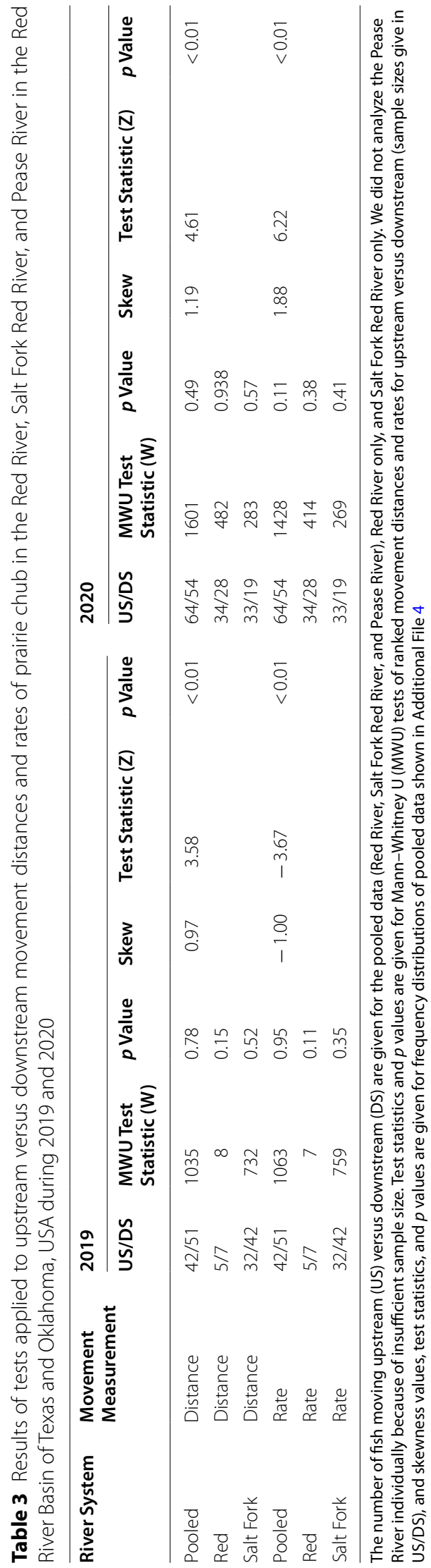


Fork Red River only (Table 3). Violin plots illustrated consistent distributions of distances moved upstream and downstream (Fig. 5a-c) as well as consistent rates moved upstream versus downstream (Fig. 5d-f). Frequency distributions plotted in continuous bins including both upstream and downstream (Additional File 4) were skewed positively for distance in 2019 and 2020, but rates were negatively skewed in 2019 and positively skewed in 2020 (Table 3). Based on these data, there was limited support for $\mathrm{H} 2$ and we concluded that prairie chub did not exhibit highly biased upstream movement during summer months of their adult life stage as predicted by the $\mathrm{CCH}$.

\section{Conservation implications}

Comparison of prairie chub with the 40 species included in the package 'fishmove' illustrated that the mobile component of the prairie chub population moved at a much higher rate $(\mathrm{m} / \mathrm{d})$ compared with other fishes, including that of other cyprinids [14]. Given their size, prairie chub movement rate was 28-times (2020) to 82-times (2019) faster than expected based on data from 40 other river fishes (Fig. 6a). Consequently, prairie chub conservation and management will likely differ from the typical riverine fish of its size. When extrapolated across the 123 days of the summer season including the months of May (31 days), June, (30 days), July (31 days), and August
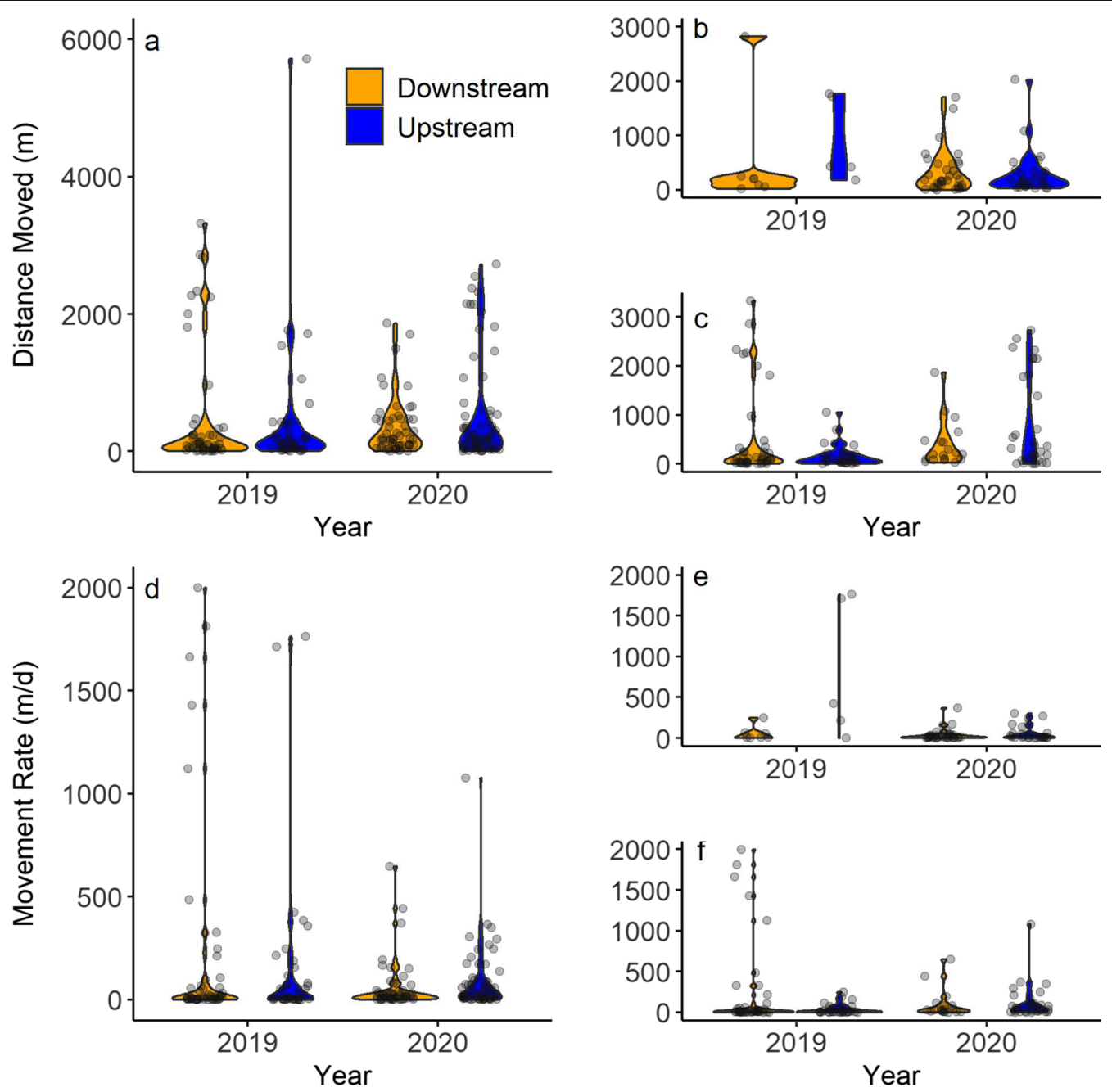

Fig. 5 Violin plots comparing $(\mathbf{a}, \mathbf{b}, \mathbf{c})$ absolute distance moved $(\mathrm{m})$ and $(\mathbf{d}, \mathbf{e}, \mathbf{f})$ movement rate $(\mathrm{m} / \mathrm{d})$ in downstream (orange) and upstream (blue) directions for prairie chub recaptured across all sites ( $\mathbf{a}, \mathbf{d} ; 2019 n=42$ upstream and $n=51$ downstream, $2020 n=64$ upstream and $n=54$ downstream), the Red River only (b, e; $2019 n=5$ upstream and $n=7$ downstream, $2020 n=34$ upstream and $n=28$ downstream), and the Salt Fork Red River only ( $\mathbf{c}, \mathbf{f} ; 2019 n=32$ upstream and $n=42$ downstream, $2020 n=33$ upstream and $n=19$ downstream) during the summers of 2019 and 2020. The Pease River was not included due to low recapture numbers $(2019 n=7,2020 n=4)$. The width of each violin plot denotes data density 

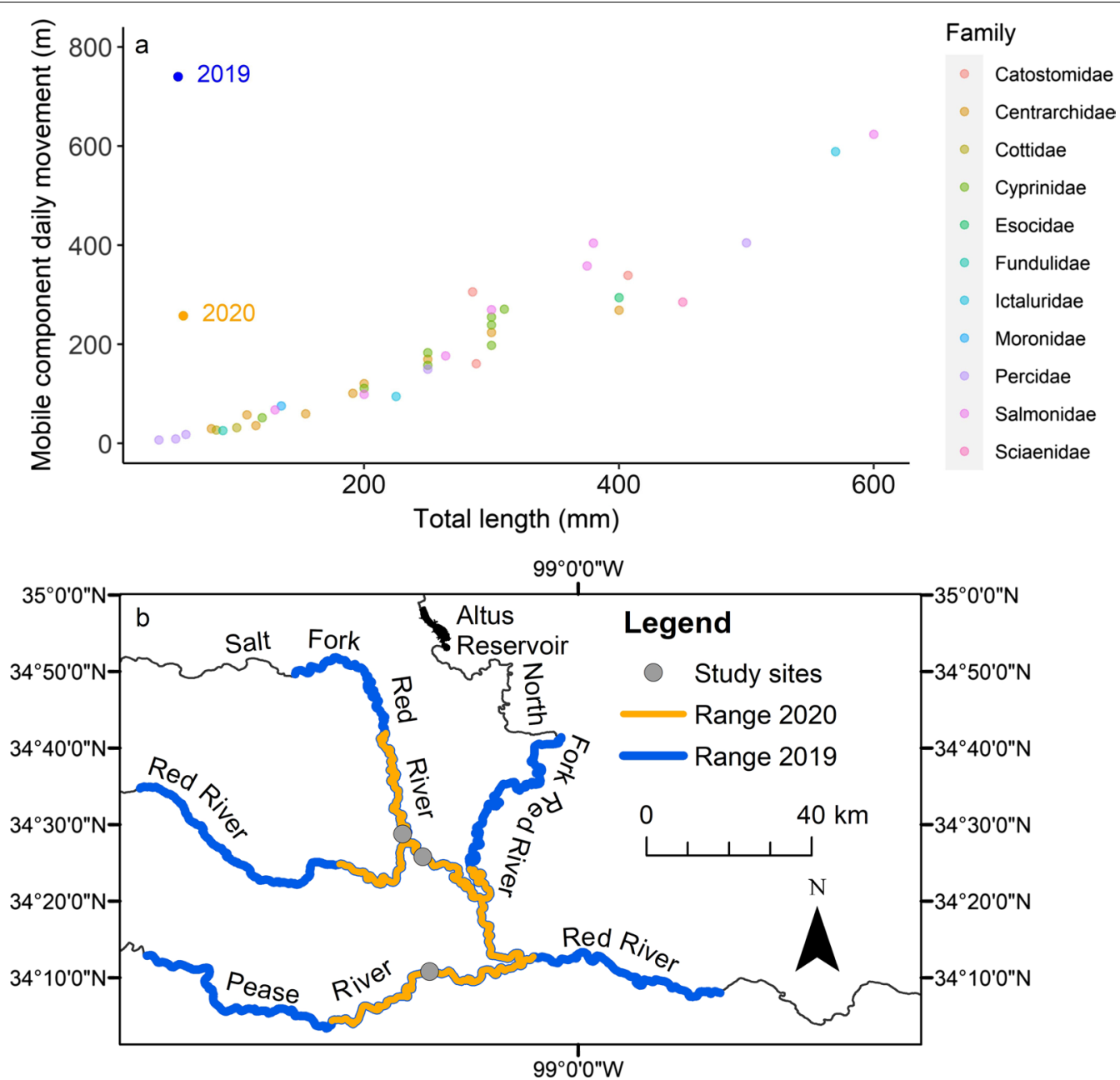

Fig. 6 a Prairie chub mobile component movement during one day (i.e., daily movement rate) for 2019 (blue) and 2020 (orange) compared with 40 other species in the figure included in the 'fishmove' package in R. Prairie chub are the only pelagic-broadcast spawner shown and was not included in the Radinger and Wolter [14] analysis. The x-axis shows mean fish total length $(\mathrm{mm})$ and the $y$-axis is the distance moved by the mobile component of populations; symbols for fishes from 'fishmove' are shown by taxonomic family with prairie chub being part of the family Cyprinidae. b Movement range (i.e., maximum distance possible during a single summer) for the mobile component of the prairie chub population for 2019 when flows were higher (blue) compared to 2020 when flows were lower (orange). Movement range is measured from the locations where fish were tagged (gray points) and does not include other locations where the species is known to occur

(31 days), the potential range of prairie chub was $31.7 \mathrm{~km}$ during 2020 and $91.0 \mathrm{~km}$ during 2019. Using only the three tagging locations as sources of movement, the mobile component range during 2020 connected the Red River mainstem, Salt Fork Red River, North Fork Red River, and Pease River, and an even larger range during 2019 included a greater extent of all these streams (Fig. 6b).

\section{Discussion}

Our study synthesizes and integrates prairie chub movement into prevailing movement theories. Ruppel et al. [48] recently inferred seasonal movement of prairie chub based on occurrence of age groups along upstream to downstream gradients in the Pease and North Fork Wichita rivers in Texas. Though the authors concluded that prairie chub are capable of long-distance upstream movements, no quantitative assessment of movement was provided. Wilde [77] used VIE tagging and mark-recapture to track movement of closely related peppered chub ( $\mathrm{Mac}$ rhybopsis tetranema) in the Canadian River of Texas, the presumed last remaining population for that species [47]. However, because of limited recaptures, movement rate could only be estimated when combined with plains minnow (Hybognathus placitus) and Arkansas River shiner (Notropis girardi) to yield a rate of $370 \mathrm{~m} / \mathrm{d}$ [77]. 
Compared with this estimate, our empirical measures of prairie chub movement rate for the mobile component were twice as fast for 2019 (i.e., $740 \mathrm{~m} / \mathrm{d}$ ) and slightly slower for 2020 (i.e., $258 \mathrm{~m} / \mathrm{d}$ ). These results collectively point to prairie chub and closely related peppered chub moving further than expected under the RMP. However, we did not find bias in summer upstream movement as would be expected under the $\mathrm{CCH}$ and as previously hypothesized for species such as peppered chub [78]. Instead, we found that summer movements were strongly leptokurtic and largely symmetrical in terms of upstream versus downstream distances. This finding is consistent with modeling simulations from Speirs and Gurney [22] and empirical results from a movement study of flathead chub (Platygobio gracilis) in a Colorado stream [43]. Speirs and Gurney [22] simulated and modelled organism persistence in environments characterized by advection (e.g., streams and rivers) and determined that the likely mechanism for upstream population persistence is diffusive dispersal rather than simply biased upstream movements. Increased dispersal, regardless of directionality, returns an ample number of individuals upstream such that populations persist at their natal upstream location. Flathead chub showed upstream bias in reproductive readiness but not movement (AprilOctober), although an artificial barrier placed on the stream blocked upstream movement. Later evidence suggested that flathead chub produce non-adhesive eggs that are potentially displaced long distances downstream, which alludes to necessary upstream movement as described by the $\mathrm{CCH}$ [79]. Thus, for at least flathead chub in Colorado and prairie chub in our study system, neither the RMP nor the $\mathrm{CCH}$ fully describes summer movement dynamics by adult fish. These findings highlight an existing drift paradox for Great Plains fishes that will only be resolved through greater focus on movement ecology $[25,26,48]$. For example, our research demonstrates that biased upstream movement does not occur for adults during summer months, but future research could uncover upstream bias by focusing on earlier life stages or other seasons.

Resolving the drift paradox for Great Plains fishes will require a deeper understanding of their reproductive biology and movement ecology. The need for ova to drift downstream in order for PBS propagules to survive was first proposed by Moore [29] for Arkansas River shiner and similar characteristics were later noted for peppered chub [27]. Later observations of spawning by PBS fishes held in captivity, including speckled chub (M. aestivalis) and sickelfin chub (M. meeki), remain some of the most detailed accounts of Great Plains PBS reproductive ecology $[28,31]$, although additional basic research on the spawning mode of prairie chub could be further studied to understand drift dynamics [40]. Properties of eggs documented during captive spawning led to the use of egg surrogates, termed passive drifting particles (PDPs), in experiments testing characteristics of drift, displacement, and retention [30, 32, 33, 35]. These works have spurred considerable debate in the literature, a debate that greater information on movements could help to resolve. For example, Medley et al. [33] modelled drift and retention of PDPs that simulated Pecos bluntnose shiner (Notropis simus pecosensis) eggs in the middle Pecos River and concluded that retention was high enough in the upstream section of river that drift into the lower, degraded reach posed little threat to the species. Thus, retention of ova and larval fishes may maintain populations upstream even in the presence of downstream drift [80, 81]. Zymonas and Propst [34] reanalyzed the PDP data presented by Medley et al. [33] and suggested that drift into the lower, degraded reach was in fact likely. Chase et al. [41] used otolith microchemistry of adult Pecos bluntnose shiner to show that $82 \%$ of specimens caught in the upper reach were originally hatched in the lower or middle reaches and moved to the upper reach while the remaining $18 \%$ of individuals hatched in the upper reach and remained residents. This example highlights that retention of at least some ova at upstream locations is possible, but the retained portion is small relative to the portion of the population that might be transported downstream. In the context of prairie chub, collection of a limited number of age- 0 individuals at upstream sites by Ruppel et al. [48] suggests that at least a portion of the population is retained upstream, but dominance of age- 0 fish downstream is consistent with either downstream displacement during drift or greater recruitment at downstream locations $[41,80,81]$. As a second example, drift rates for PDPs in the North Canadian and Canadian rivers in Oklahoma, two systems comparable to the Red River, ranged $0.07-0.55 \mathrm{~m} / \mathrm{s}$ depending on discharge and channel geomorphology [32]. These rates equate to $6-47 \mathrm{~km} / \mathrm{d}$ and over a 3 -day period (i.e., presumed larval development timing; [31]) could result in downstream distances ranging 18-143 km. If consistent drift distances occur in the Red River system, our data suggest the mobile component of the prairie chub population could move comparable distances (i.e., $32-91 \mathrm{~km}$ ) within in a single summer. The conservation of PBS fishes will ultimately require additional research on reproductive life history [40]. Our results provide previously unquantified aspects of adult movement ecology and the appropriate scale of habitat conservation for an imperiled and presumed member of this reproductive guild.

Prairie chub and other ecologically similar species may benefit from management activities that maintain flow and habitat connectivity. Dudley and Platania [30] 
demonstrated the combined threats that flow alteration and habitat fragmentation pose to PBS fishes, particularly downstream transport of ova into reservoirs where survival and recruitment are presumed limited. Results from several studies in the Great Plains show local extirpations of PBS fishes in truncated stream fragments [30, $32,36,48]$, though the mechanisms are debated. Hoagstrom [37] suggested there was a lack of evidence that fragmentation alone had contributed to PBS fish extirpation, but Wilde and Urbanczyk [38] provided examples of extirpations that occurred upstream of large barriers where interrupted dispersal was a likely explanation. In fact, prairie chub extirpation from the North Fork Red River upstream of Altus Reservoir was attributed to habitat fragmentation [53]. More recently, studies have documented the loss of PBS fishes, including Macrhybopsis spp., from fragmented streams that either suffer the effects of extreme drought (e.g., $(55,82))$ or the long-term effects of water depletion, extraction, or diversion (e.g. irrigation; [49]). Extreme drought events are known to suppress or thwart recruitment of PBS fishes [83, 84], and under scenarios of local extirpation, populations can only persist when recolonization is possible. Mollenhauer et al. [85] assessed broad-scale occurrence and detection patterns for prairie chub and found detection was lower during extended dry periods compared to wet periods, however, occurrence was only marginally different. We found evidence of greater dispersal in 2019 when flows were higher compared to 2020, which may relate to increased overall detection (i.e., more sites with fish). Further hypothesis testing is needed to completely understand the linkage between flow and dispersal, but positive correlations between flow and dispersal are apparent in other fish populations [15, 76]. Prior to our study, the distances PBS fishes such as prairie chub were able to move to (re)colonize river segments was largely unknown outside of qualitative descriptions of "long distances" [48]. Our work provides empirical evidence for high dispersal and potential movement ranges that far exceed those expected for the average river fish. The validity of this finding is further supported from documented movement by plains killifish (Fundulus zebrinus) studied in the same system using the same methods as our study of prairie chub. In particular, plains killifish movement shows strong consistency with the RMP while prairie chub movement does not [16].

Although we provide insight into movements by prairie chub across two summers, our study has a several limitations and continued research may improve understanding of the movement ecology of this species. We tagged prairie chub fish during the known spawning season (April-September; [48]) when gravid females were present. However, it is possible that movement is hindered during this time because fish are contributing energy to reproduction or risk avoidance from predators [64], and movement might have occurred earlier in the year. Furthermore, our study was limited to tracking movements of adult individuals ranging $45-70 \mathrm{~mm} \mathrm{TL}$. It is possible that there is an upstream bias in movement among smaller individuals that were too small to tag with VIE (e.g., [25]) as demonstrated by PBS species Pecos bluntnose shiner [41]. We also suggest that basic life history research on ova characteristics of prairie chub and other suspected PBS fishes be done to compliment previous studies [40,48]. Future studies gathering individual information across a broader range of fish sizes, ages, and seasons would address these limitations of our study. The use of p-chips or other tagging methods to collect individual movement data for diminutive fishes as small as $20 \mathrm{~mm}$ standard length [86] would be a good strategy. Another limitation to our study was sample size, though our recapture rate (i.e., 3.8\%) was similar to other studies that used VIE on freshwater PBS fishes. Platania et al. [26] tagged 11,500 Rio Grande silvery minnow (Hybognathus amarus) and had a $0.6 \%$ recapture rate, while Wilde [77] tagged three PBS species with recapture rates varying from $1.4 \%$ for Arkansas River shiner, $0.8 \%$ for plains minnow, and $8.7 \%$ for peppered chub. However, we argue that recapture number is more important than percentage (e.g., $50 \%$ recapture of 6 individuals would not give enough statistical power to analyze an entire population) and our numbers of recaptured fish matched or exceeded previous movement studies of fishes $[15,26]$. However, we also point out that failure to recapture all or a majority of the tagged individuals, even between years, could be due to movement outside our search areas, predation or other mortality (i.e. two year life span), loss of tags, or non-detection because of imperfect sampling methods. One of the benefits of our study design over previous mark-recapture studies of PBS fishes (e.g., [77]) is that we searched evenly upstream and downstream instead of biasing searches in upstream locations. Albanese et al. [87] suggested that when designing a mark-recapture study, it is important to search equal distances upstream and downstream to reduce bias. Finally, our basis of comparison with the RMP was a meta-analysis that included few small-bodied fishes in large rivers (as highlighted by Archdeacon et al. [88]) and studies such as ours that address this paucity will ultimately improve empirical tests of movement theories.

From a conservation perspective, knowledge that fractions of prairie chub populations make long-distance movements can inform decisions related to maintaining habitat connectivity and flow-based habitat integrity. Historical range reduction of prairie chub has occurred in fragmented habitats where access is now blocked 
by reservoir dams $[48,53]$. The largest of these habitats is located far upstream within the North Fork of the Red River and if not blocked by a dam would be within the swimming range of the mobile component of the population in the lower North Fork Red River based on our results. We hypothesize that this area historically required meta-population connectivity over broad spatial extents, perhaps because temporally variable desiccation disturbances are more effective at causing population declines in smaller streams [82]. Consequently, consideration of species occurrences (or loss of occurrence after habitat alteration) should account for the fact that movement might be a critical aspect of niche definition [90]. This is the basis for greater integration of movement ecology into conservation biology [1]. One concept in particular that might be useful for organisms such as prairie chub that occupy highly variable habitats is the idea that movement is not classified as migratory or resident, but might instead be nomadic. Teitelbaum and Mueller [91] reviewed nomadic movements by animals and concluded that ecosystems with high inter-annual environmental variability should select for nomadic movements, and within these ecosystems variation in movement among individuals could manifest as mixes of stationary and randomly mobile behaviors as we observed for prairie chub (especially with regard to upstream vs downstream directions). Runge et al. [3] further suggested that conservation of species that display nomadic movements can be challenging because their geographic distributions are viewed and managed as static when in fact, they may be temporally dynamic and strongly tied to movement. Consequently, conservation-focused management actions for prairie chub would benefit from consideration of maintaining connectivity on the order of $10^{3}-10^{5} \mathrm{~m}$ [7] and across a range of habitats including mainstem and tributary ecosystems [92].

\section{Conclusions}

We employed a mark-recapture study at an unprecedented spatial extent (i.e., recurrent continuous searches five $\mathrm{km}$ in length) and found that prairie chub movement was at least an order of magnitude greater than expected under the prevailing stream fish movement ecology paradigm (i.e., the RMP; $[10,15])$. This finding supports earlier observations and hypotheses related to fishes such as prairie chub engaging in longdistance movements over relatively short temporal extents (i.e., within a single summer; $[48,77,89])$. However, we found only limited evidence for the presumed upstream bias in movement frequently ascribed to PBS fishes [28]. Specifically, distances moved upstream versus downstream did not differ despite positive skewness in most movement distributions. These seemingly contradictory patterns in which fish move great distances but not in a synchronized upstream fashion present a paradoxical situation in which upstream populations of prairie chub persist despite presumed downstream drift at early life stages (i.e., the DP; [1921]). The resolution to this paradox is likely related to two features of their ecology. First, downstream displacement of ova is unlikely to be uniform and therefore some upstream retention is plausible in this system [41, 80, 81]. Second, previous modelling and real-world observations in stream systems show that increased dispersal (even in the absence of upstream biased dispersal) is sufficient to facilitate population persistence when critical lengths of habitat persist [22]. These observations advance an emerging narrative in which PBS fishes require minimum fragment lengths [45], are subject to increased downstream displacement under modified flows [30], and experience some upstream retention [41, 44, 80, 81], but do not show strongly biased upstream movement $[26,42,43]$.

\section{Abbreviations}

RMP: Restricted movement paradigm; $\mathrm{CCH}$ : Colonization cycle hypothesis; DP: Drift paradox; PBS: Pelagic-broadcast spawning; TL: Total length; d: Days; mm: Millimeters; $\mathrm{cm}$ : Centimeters; VIE: Visible implant elastomer.

\section{Supplementary Information}

The online version contains supplementary material available at https://doi. org/10.1186/s40462-022-00306-9.

Additional file 1. Hydrographs for the Red River (U.S. Geological Survey gage \# 07308500), Salt Fork Red River (USGS gage \# 07301110), and Pease River (USGS gage \# 07308200) indicating daily discharge from May through September of (a) 2019 and (b) 2020. Lines are colored by river and similarly colored points on lines represent sampling dates. Note the $y$-axis is shown on a $\log _{10}$ scale.

Additional file 2. Conceptual diagram for a visible implant elastomer (VIE) mark-recapture study to assess movement of Prairie Chub. On each of three tributaries, we established a study segment that was $5 \mathrm{~km}$ in length. The study segments comprised 5, 1-km reaches. Every other reach was a search or tagging reach, in which fishes were either only searched for (i.e., search reach) or tagged and searched for (i.e., tag reach). Each tag reach comprised 5, 0.2-km sub-reaches, and within these sub-reaches fish were batch marked with sub-reach-specific body locations. This allowed greater resolution of fish movement during recaptures. During each tagging trip, a new color of VIE was used so that time at large (days) for recaptured individuals could be calculated and associated with a particular date. Picture of VIE tags are from Northwest Marine Technology Inc. and the black and white chub picture is from Everman [82]. There are examples of tagged prairie chub with various VIE colors.

Additional file 3 . This file contains the $\mathrm{R}$ code used in this manuscript and data files used in analysis.

Additional file 4. Frequency histograms of prairie chub movement distance $(\mathrm{m})$ and rate $(\mathrm{m} / \mathrm{d})$ for $2019(\mathrm{a}, \mathrm{c} ; \mathrm{n}=94)$ and $2020(\mathrm{~b}, \mathrm{~d} ; \mathrm{n}=119)$. Colors correspond with fish recaptured in the Pease River (green), Red River (orange), and Salt Fork Red River (blue) and are shown as stacked bars. Negative values represent downstream movement and positive values represent upstream movement. Distance moved is shown using $100 \mathrm{~m}$ bins and movement rate is shown using $50 \mathrm{~m}$ bins. 


\section{Acknowledgements}

We thank the Oklahoma Department of Wildlife Conservation for funding as well as a Sigma Xi Grant in Aid of Research awarded to ZDS for funding to purchase tagging equipment. We thank Gail, Bambi, and Kyle Mayfield, Austin Stafford, and Matt Acre for their help on this project. We also thank all the landowners that allowed us to access their properties and conduct field work. This study was performed under the auspices of the Texas A\&M University Institutional Animal Care and Use Committee (Animal Use Protocol 2018-0059 M). We would also like to thank the Texas A\&M Department of Ecology and Conservation Biology for providing grant funds for open access. Any use of trade, firm, or product names is for descriptive purposes only and does not imply endorsement by the U.S. Government.

\section{Authors' contributions}

Study Design—Z.S., J.P., S.B. Data Collection-Z.S., J.P., L.Y., N.S., Data AnalysisZ.S., J.P., Manuscript Writing - Z.S., J.P., S.B., M.W., L.Y., N.S. The authors read and approved the final manuscript.

\section{Funding}

The authors thank the Oklahoma Department of Wildlife Conservation and Sigma Xi for funding this project.

\section{Availability of data and materials}

All data generated and analyzed from this study are included in the published article and supplementary materials.

\section{Declarations}

\section{Consent for publication}

Not applicable.

\section{Competing interests}

The authors declare that they have no competing interests.

\section{Author details}

${ }^{1}$ Department of Ecology and Conservation Biology, Texas A\&M University, College Station, TX, USA. ${ }^{2}$ Ecology and Evolutionary Biology Program, Texas A\&M University, College Station, TX, USA. ${ }^{3}$ Oklahoma State University, Stillwater, OK, USA. ${ }^{4}$ U.S. Geological Survey, AL Cooperative Fish and Wildlife Research Unit, Auburn University, Auburn, AL, USA.

Received: 24 September 2021 Accepted: 7 February 2022 Published online: 22 February 2022

\section{References}

1. Ogburn MB, Harrison AL, Whoriskey FG, Cooke SJ, Mills Flemming JE, Torres LG. Addressing challenges in the application of animal movement ecology to aquatic conservation and management. Front Mar Sci. 2017:4:1-7.

2. Cooke SJ, Paukert C, Hogan Z. Endangered river fish: factors hindering conservation and restoration. Endanger Species Res. 2012;17(2):179-91.

3. Runge CA, Martin TG, Possingham HP, Willis SG, Fuller RA. Conserving mobile species. Front Ecol Environ. 2014;12:395-402.

4. Katzner TE, Arlettaz R. Evaluating contributions of recent tracking-based animal movement ecology to conservation management. Front Ecol Evol. 2020;7:1-10

5. Fraser KC, Davies KTA, Davy CM, Ford AT, Flockhart DTT, Martins EG. Tracking the conservation promise of movement ecology. Front Ecol Evol. 2018:6:1-8.

6. Allen AM, Singh NJ. Linking movement ecology with wildlife management and conservation. Front Ecol Evol. 2016;3:1-13.

7. Fausch KD, Torgersen CE, Baxter CV, Li HW. Landscapes to riverscapes: bridging the gap between research and conservation of stream fishes. Bioscience. 2002;52(6):483-98

8. Gerking SD. Evidence for the concepts of home range and territory in stream fishes. Ecology. 1953;34(2):347-65.

9. Gerking SD. The restricted movement of fish populations. Biol Rev. 1959:34(2):221-42.
10. Funk JL. Movement of stream fishes in Missouri. Trans Am Fish Soc. 1957;85(1):39-57.

11. Gowan C, Young MK, Fausch KD, Riley SC. Restricted movement in resident stream salmonids: a paradigm lost? Can J Fish Aquat Sci. 1994:51:2626-37.

12. Rodriguez MA. Restricted movement in stream fish: the paradigm is incomplete, not lost. Ecology. 2002;83(1):1-13.

13. Skalski GT, Gilliam JF. Modeling diffusive spread in a heterogeneous population: a movement study with stream fish. Ecology. 2000;81(6):1685-700

14. Radinger J, Wolter C. Patterns and predictors of fish dispersal in rivers. Fish Fish. 2014;15(3):456-73.

15. Wells WG, Johnson TC, Gebhard AE, Paine RTR, Hix LA, Ferrell HN, et al. March of the sculpin: measuring and predicting short-term movement of banded sculpin Cottus carolinae. Ecol Freshw Fish. 2017;26:280-91.

16. Santee NS, Yancy LE, Steffensmeier ZD, Perkin JS. Testing restricted movement of plains killifish (Fundulus zebrinus). Southwest Nat. 2021. In Press.

17. Muller K. Investigations on the organic drift in North Swedish streams. Rep Inst Freshw Res Drottningholm. 1954;35:133-48.

18. Müller K. The colonization cycle of freshwater insects. Oecologia. 1982;52(2):202-7.

19. Humphries S, Ruxton GD. Is there really a drift paradox? J Anim Ecol. 2010;71(1):151-4

20. Hershey AE, Pastor J, Peterson BJ, Kling GW. Stable isotopes resolve the drift paradox for Baetis mayflies in an Arctic River. Ecology. 1993;74(8):2315-25.

21. Anholt BR. Density dependence resolves the stream drift paradox. Ecology. 1995;76(7):2235-9

22. Speirs DC, Gurney WSC. Population persistence in rivers and estuaries. Ecol Soc Am. 2001;82:1219-37.

23. Pachepsky E, Lutscher F, Nisbet RM, Lewis MA. Persistence, spread and the drift paradox. Theor Popul Biol. 2005;67(1):61-73.

24. Naman SM, Rosenfeld JS, Richardson JS. Causes and consequences of invertebrate drift in running waters: from individuals to populations and trophic fluxes. Can J Fish Aquat Sci. 2016;73(8):1292-305.

25. Archdeacon TP, Davenport SR, Grant JD, Henry EB. Mass upstream dispersal of pelagic-broadcast spawning cyprinids in the Rio Grande and Pecos River. New Mexico West N Am Nat. 2018:78(1):100-5.

26. Platania SP, Mortensen JG, Farrington MA, Brandenburg WH, Dudley RK. Dispersal of stocked Rio Grande silvery minnow (Hybognathus amarus) in the middle Rio Grande. New Mexico Southwest Nat. 2020;64(1):31-42.

27. Bottrell CE, Ingersol RH, Jones RW. Notes on the embryology, early development, and behavior of Hybopsis aestivalis tetranemus (Gilbert). Trans Am Microsc Soc. 1964;83(4):391-9.

28. Platania SP, Altenbach CS. Reproductive strategies and egg types of seven Rio Grande Basin cyprinids. Copeia. 1998;1998(3):559-69.

29. Moore GA. Notes on the early life history of Notropis girardi. Copeia. 1944:4:209-14

30. Dudley RK, Platania SP. Flow regulation and fragmentation imperil pelagic-spawning riverine fishes. Ecol Appl. 2007;17(7):2074-86.

31. Albers JL, Wildhaber ML. Reproductive strategy, spawning induction, spawning temperatures and early life history of captive sicklefin chub Macrhybopsis meeki. J Fish Biol. 2017:91(1):58-79.

32. Worthington TA, Brewer SK, Farless N, Grabowski TB, Gregory MS. Interacting effects of discharge and channel morphology on transport of semibuoyant fish eggs in large, altered river systems. PLoS ONE. 2014;9(5):1-9.

33. Medley CN, Kehmeier JW, Myers OB, Valdez RA. Simulated transport and retention of pelagic fish eggs during an irrigation release in the pecos river, new Mexico. J Freshw Ecol. 2007;22(3):499-513.

34. Zymonas ND, Propst DL. A re-analysis of data and critique of medley et al.-_"simulated transport and retention of pelagic fish eggs during an irrigation release in the pecos river, new Mexico." J Freshw Ecol. 2009;24(4):671-9.

35. Widmer AM, Fluder JJ III, Kehmeier JW, Medley CN, Valdez RA. Drift and retention of pelagic spawning minnow eggs in a regulated river. River Res Appl. 2012;28(2):192-203.

36. Wilde GR, Urbanczyk AC. Relationship between river fragment length and persistence of two imperiled great plains cyprinids. J Freshw Ecol. 2013;28(3):445-51.

37. Hoagstrom CW. Drift versus retention: an alternative perspective to Wilde and Urbanczyk's relationship between river fragment length 
and persistence of two imperiled great plains cyprinids. J Freshw Ecol. 2014;29(3):449-52.

38. Wilde GR, Urbanczyk AC. Speculation but no data: a response to Hoagstrom's drift versus retention perspective. J Freshw Ecol. 2014;29(3):453-5.

39. Hoagstrom CW. Habitat loss and subdivision are additive mechanisms of fish extinction in fragmented rivers. Glob Change Biol. 2014;1 (21):4-5.

40. Worthington TA, Echelle AA, Perkin JS, Mollenhauer R, Farless N, Dyer $J$ J, et al. The emblematic minnows of the North American Great Plains: a synthesis of threats and conservation opportunities. Fish Fish. 2018;19:271-307.

41. Chase NM, Caldwell CA, Carleton SA, Gould WR, Hobbs JA. Movement patterns and dispersal potential of pecos bluntnose shiner (Notropis simus pecosensis) revealed using otolith microchemistry. Can J Fish Aquat Sci. 2015;72:1575-83.

42. Archdeacon TP, Remshardt WJ. Observations of hatchery-reared Rio Grande silvery minnow using a fishway. N Am J Fish Manag. 2012;32(4):648-55.

43. Walters DM, Zuellig RE, Crockett HJ, Bruce JF, Lukacs PM, Fitzpatrick RM. Barriers impede upstream spawning migration of flathead chub. Trans Am Fish Soc. 2014;143(1):17-25.

44. Hoagstrom CW, Turner TF. Recruitment ecology of pelagic-broadcast spawning minnows: paradigms from the ocean advance science and conservation of an imperilled freshwater fauna. Fish Fish. 2015;16(2):282-99.

45. Perkin JS, Gido KB. Stream fragmentation thresholds for a reproductive guild of great plains fishes. Fisheries. 2011;36(8):371-83.

46. Luttrell GR, Echelle AA, Fisher WL, Eisenhour DJ. Declining status of two species of the Macrhybopsis aestivalis complex (Teleostei: Cyprinidae) in the Arkansas River Basin and related effects, of reservoirs as barriers to dispersal. Copeia. 1999;1999(4):981-9.

47. Pennock CA, Gido KB, Perkin JS, Weaver VD, Davenport SR, Caldwell JM. Collapsing range of an endemic Great Plains Minnow, Peppered Chub Macrhybopsis tetranema. Am Midl Nat. 2017;177:57-68.

48. Ruppel DS, Sotola VA, Craig CA, Martin NH, Bonner TH. Assessing functions of movement in a Great Plains endemic fish. Environ Biol Fishes. 2020;103:795-814.

49. Perkin JS, Gido KB, Cooper AR, Turner TF, Osborne MJ, Johnson ER, et al. Fragmentation and dewatering transform Great Plains stream fish communities. Ecol Monogr. 2015;85(1):73-92.

50. Eisenhour DJ. Systematics, variation, and speciation of the Macrhybopsis aestivalis complex west of the Mississippi River. Bull Alabama Museum Nat Hist. 2004;23:9-48.

51. Jelks HL, Walsh SJ, Burkhead NM, Contreras-Balderas S, Diaz-Pardo E, Hendrickson DA, et al. Conservation status of imperiled North American freshwater and Diadromous fishes. Fisheries. 2008;33(8):372-407.

52. Birdsong TW, Garrett GP, Bean MG, Curtis SG, Mayes KB. Conservation status of Texas freshwater fishes: informing state-based species protections. J Southwest Assoc Fish Wild Agencies. 2020;8:40-52.

53. Winston MR, Taylor CM, Pigg J. Upstream extirpation of four minnow species due to damming of a prairie stream. Trans Am Fish Soc. 1991;120(1):98-105

54. Taylor CM. Covariation among plains stream fish assemblages, flow regimes, and patterns of water use. Am Fish Soc Symp. 2010;73:447-59.

55. Perkin JS, Gido KB, Costigan KH, Daniels MD, Johnson ER. Fragmentation and drying ratchet down Great Plains stream fish diversity. Aquat Conserv Mar Freshw Ecosyst. 2015;25(5):639-55.

56. Dodds WK, Gido K, Whiles MR, Fritz KM, Matthews WJ. Life on the edge: the ecology of Great Plains prairie streams. Bioscience. 2004;54(3):205-16.

57. Gotelli NJ, Taylor CM. Testing metapopulation models with stream-fish assemblages. Evol Ecol Res. 1999; 1 (7):835-45.

58. Benke AC, Cushing CE. Rivers of North America. New York City: Elsevier; 2005. p. 282-325.

59. Strahler AN. Quantitative analysis of watershed geomorphology. Eos, Trans Am Geophys Union. 1957:38(6):913-20.

60. Alex Sotola V, Ruppel DS, Bonner TH, Nice CC, Martin NH. Asymmetric introgression between fishes in the Red River basin of Texas is associated with variation in water quality. Ecol Evol. 2019;9(4):2083-95.

61. McKay L, Bondelid T, Dewald T, Johnston J, Moore R, Rea A. NHDPlus Version 2: User Guide. 2012.

62. Olsen EM, Vøllestad LA. An evaluation of visible implant elastomer for marking age-0 brown trout. N Am J Fish Manag. 2001;21(4):967-70.
63. Musselman WC, Worthington TA, Mouser J, Williams DM, Brewer SK. Passive integrated transponder tags: review of studies on warmwater fishes with notes on additional species. J Fish Wildl Manag. 2017:8(2):353-64.

64. Pennock CA, Frenette BD, Waters MJ, Gido KB. Survival of and tag retention in Southern Redbelly dace injected with two sizes of PIT tags. N Am J Fish Manag. 2016;36(6):1386-94.

65. Fraser DF, Gilliam JF, Daley MJ, Le AN, Skalski GT. Explaining leptokurtic movement distributions: intrapopulation variation in boldness and exploration. Am Natur. 2001:158(2):124-35.

66. Jungwirth A, Balzarini V, Zöttl M, Salzmann A, Taborsky M, Frommen JG. Long-term individual marking of small freshwater fish: the utility of Visual Implant Elastomer tags. Behav Ecol Sociobiol. 2019;73(4):1-1.

67. Moore DM, Brewer SK. Evaluation of visual implant elastomer, PIT, and p-chip tagging methods in a small-bodied minnow species. N Am J Fish Manag. 2021:41:1066-78.

68. Luttrell GR, Echelle AA, Fisher WL. Habitat Correlates of the Distribution of Macrhybopsis hyostoma (Teleostei: Cyprinidae) in Western Reaches of the Arkansas River Basin. Trans Kansas Acad Sci. 2002;105(3):153-61.

69. Pauly D. Food consumption by tropical and temperate fish populations: some generalizations. J Fish Biol. 1989;35:11-20.

70. Thomas U. North American Native Fishes Association. http://gallery.nanfa. org/v/members/Uland/Family+Cyprinidae/Macrhybopsis/Macrhybops is+australis+Prairie+Chub+4333ws.JPG.html?g2_imageViewslndex=2. Accessed 20 May 2021

71. D'Agostino R, Pearson ES. Tests for departure from normality. Empirical results for the distributions of b2 and $\sqrt{ }$ b1. Biometrika. 1973;60(3):613-22.

72. Anscombe FJ, Glynn WJ. Distribution of the kurtosis statistic b2 for normal samples. Biometrika. 1983;70(1):227-34.

73. Petty JT, Grossman GD. Restricted movement by mottled sculpin (pisces: cottidae) in a southern Appalachian stream. Freshw Biol. 2004:49(5):631-45.

74. Hudy M, Shiflet J. Movement and recolonization of Potomac sculpin in a Virginia stream. N Am J Fish Manag. 2009;29(1):196-204.

75. Bauer DF. Constructing confidence sets using rank statistics. J Am Stat Assoc. 1972:67(339):687-90.

76. Cooke SJ, Martins EG, Struthers DP, Gutowsky LFG, Power M, Doka S, et al. A moving target-incorporating knowledge of the spatial ecology of fish into the assessment and management of freshwater fish populations. Environ Monit Assess. 2016;44:0-19.

77. Wilde GR. Final report: migration of Arkansas River shiner and other broadcast spawning fishes in the Canadian River, New Mexico-Texas. Great Plains Landscape Conservation Cooperative. 2016.

78. Bonner, T. H. Life history and reproductive ecology of the Arkansas River shiner and peppered chub in the Canadian river, Texas and New Mexico. Doctoral dissertation. Texas Tech University, Lubbock. 2000

79. Bestgen KR, Crockett HJ, Haworth MR, Fitzpatrick RM. Production of nonadhesive eggs by flathead chub and implications for downstream transport and conservation. J Fish Wildl Manag. 2016;7(2):434-43.

80. Valdez RA, Haggerty GM, Richard K, Klobucar D. Managed spring runoff to improve nursery floodplain habitat for endangered Rio Grande silvery minnow. Ecohydrology. 2019;12(7):e2134.

81. Valdez RA, Zipper SA, Kline SJ, Haggerty GM. Use of restored floodplains by fishes of the Middle Rio Grande, New Mexico, USA. Ecohydrology. 2021;14(2):e2262.

82. Perkin JS, Shattuck ZR, Gerken JE, Bonner TH. Fragmentation and drought legacy correlate with distribution of Burrhead Chub in subtropical streams of North America. Trans Am Fish Soc. 2013;142(5):1287-98.

83. Perkin JS, Starks TA, Pennock CA, Gido KB, Hopper GW, Hedden SC. Extreme drought causes fish recruitment failure in a fragmented Great Plains riverscape. Ecohydrology. 2019;12(6):1-12.

84. Archdeacon TP, Diver-Franssen TA, Bertrand NG, Grant JD. Drought results in recruitment failure of Rio Grande silvery minnow (Hybognathus amarus), an imperiled, pelagic broadcast-spawning minnow. Environ Biol Fishes. 2020;103(9):1033-44.

85. Mollenhauer R, Brewer SK, Perkin JS, Swedberg D, Wedgeworth M, Steffensmeier ZD. Connectivity and flow regime direct conservation priorities for pelagophil fishes. Aquat Conserv Mar Freshw Ecosyst. 2021;31:1-13.

86. Faggion S, Sanchez P, Vandeputte M, Clota F, Vergnet A, Blanc MO, Allal F. Evaluation of a European sea bass (Dicentrarchus labrax L.) post-larval tagging method with ultra-small RFID tags. Aqua. 2020;520:734945. 
87. Albanese B, Angermeier PL, Gowan C. Designing mark-recapture studies to reduce effects of distance weighting on movement distance distributions of stream fishes. Trans Am Fish Soc. 2003;132(5):925-39.

88. Archdeacon TP, Gonzales EJ, Thomas LI. Movement of Red Shiner during a regulated, intentional surface-flow recession. Ecol Freshw Fish. 2021:00:1-11

89. Cross FB. Effects of sewage and of a headwaters impoundment on the fishes of Stillwater Creek in Payne County. Oklahoma Am Midl Nat. 1950:43(1):128-45.

90. Soberón J. Grinnellian and Eltonian niches and geographic distributions of species. Ecol Lett. 2007;10:1115-23.

91. Teitelbaum CS, Mueller T. Beyond migration: causes and consequences of nomadic animal movements. Trends Ecol Evol. 2019;34:569-81.

92. Pracheil BM, McIntyre PB, Lyons JD. Enhancing conservation of largeriver biodiversity by accounting for tributaries. Front Ecol Environ. 2013;11:124-8.

\section{Publisher's Note}

Springer Nature remains neutral with regard to jurisdictional claims in published maps and institutional affiliations.

- fast, convenient online submission

- thorough peer review by experienced researchers in your field

- rapid publication on acceptance

- support for research data, including large and complex data types

- gold Open Access which fosters wider collaboration and increased citations

- maximum visibility for your research: over $100 \mathrm{M}$ website views per year

At BMC, research is always in progress.

Learn more biomedcentral.com/submissions 